\title{
Stereotypy polityków w kampaniach wyborczych
}

\section{Stereotypes of Politicians in Election Campaigns}

Stowa kluczowe: stereotyp, autostereotyp, heterostereotyp, metastereotyp, kampania wyborcza

Keywords: stereotype, auto-stereotype, hetero-stereotype, meta-stereotype, election campaign

Abstrakt: Przedmiot publikacji stanowi analiza roli stereotypów społecznych w kampaniach wyborczych. Pierwsza część dotyczy zagadnień definicyjnych stereotypu i jego relacji podmiotowo-przedmiotowej w rzeczywistości politycznej. Następnie w odniesieniu do działań marketingowo-propagandowych przywołane zostaja cztery pragmatyczne funkcje kampanii wyborczej: lokalizacyjna, wartościująco-postulatywna, socjotechniczna $i$ programowa, które koreluja z czterema podstawowymi funkcjami stereotypów: poznawcza, integracyjna, obronna i adaptacyjnq. Do każdej z funkcji przyporzadkowano dominujące w polskiej polityce stereotypy.

Abstract: The subject of the following paper is an analysis of the role social stereotypeshavein election campaigns. The first part concerns the definition of the stereotype and its subject-object relation in political reality. Consequently, when considering the marketing and propaganda actions, four pragmatic functions of political campaigns are evoked: location, values and the demands of the autogroup, social engineering and election program, which are related to the four basic functions of stereotypes: cognitive, integrative, defending and adaptive. Every single function is assigned to the stereotypes, which are dominant in Polish politics.

* ORCID ID: https://orcid.org/0000-0003-3819-6857, zajmuje się biznesem, kampaniami wyborczymi i bankowością. 


\section{Wprowadzenie}

Prezentowana publikacja odnosi się do pewnej luki, którą dostrzec można, analizując kierunek deskrypcji i eksplanacji zjawisk politycznych w polskiej psycho i socjo-politologii, w odniesieniu do takich zagadnień, jak: kultura polityczna, postawy czy komunikowanie polityczne. W opracowaniach wielu polskich autorów pojęcie stereotypu jest często pomijane lub traktuje się je marginalnie, nawet, kiedy styczność badanych zjawisk $\mathrm{z}$ teorią stereotypów jest ewidentna. Z nielicznymi wyjątkami, nie występują próby zastosowania pojęcia stereotypu jako kategorii centralnej, wokół której budowany jest dyskurs naukowy, w przeciwieństwie do prac powstałych na gruncie psychologii i socjologii. Badanie stereotypu ma raczej charakter rozproszony, a jego aplikacja do wydarzeń bieżących, kształtujących scenę polityczną jest znikoma. A to przecież stereotyp, który z racji swojej natury zakorzeniony jest $\mathrm{w}$ tradycji i kulturze danego społeczeństwa oraz w aparacie poznawczym człowieka, ma jako pojęcie charakter integrujący dla takich problemów, jak: percepcja, wizerunek, język polityki, preferencje polityczne, postawy i decyzje wyborcze, treść kampanii wyborczej, propaganda czy ideologia. Ten zbiór jest zbiorem otwartym.

Badacze polityki, jak A. Schaff i J. Błuszkowski dają warsztat teoretyczno-metodologiczny do analizy zjawisk politycznych w odniesieniu do stereotypów, a wręcz postulują o badanie polityki pod tym kątem, ze względu na istotną rolę stereotypu w procesach politycznych i walory heurystyczne wynikające z zastosowania tego pojęcia. Brak kontynuacji ustaleń A. Schaffa, dotyczących instrumentalnego wykorzystania stereotypów w walce politycznej, dałoby się wyjaśnić właśnie negatywnym stereotypem i daleko idącą poprawnością polityczną wobec nauki uprawianej na gruncie marksistowskim. Z perspektywy badacza, odrzucenie tych stereotypowych prekoncepcji, pozwala na neutralne sięgnięcie i wykorzystanie dorobku A. Schaffa w zakresie stereotypów w obecnych realiach, przypomnijmy, człowieka ugruntowanego w teorii i praktyce tworzenia ideologii i propagandy. Dorobku, wskazującego na rolę, jaką stereotypy pełnią w oddziaływaniu na masy ludzkie. Warto także zauważyć, że jedne pierwszych teorii, wyjaśniających występowanie stereotypów w społeczeństwie, dotyczą walki o pewne, ograniczone zasoby, w tym o władzę ${ }^{1}$, stąd niniejsza praca ma na celu wskazanie na gruncie teoretycznym, istotnych z punktu widzenia wyborów i kampanii wyborczych

1 Zob. M. Kofta, Wprowadzenie do psychologii stereotypów i uprzedzeń, [w:] E. Gucwa-Leśny, M. Marody (red.), Podstawy życia społecznego w Polsce, Warszawa 1996, s. 200. 
pragmatycznych obszarów występowania stereotypów w kontekście walki wyborczej.

Trzeba pamiętać, że proces stereotypizacji dotyczy każdego człowieka, charakteryzuje on aparat poznawczy gatunku ludzkiego w związku $\mathrm{z}$ wytworzeniem komunikacji ustrukturyzowanej w języku, uczestnictwem w kulturze i społeczności oraz cechom indywidualnym poszczególnych jednostek ${ }^{2}$. Pomimo różnych podejść, związanych z eksploracją zjawiska stereotypu na gruncie wielu dyscyplin naukowych, panuje szeroko pojęta akceptacja co do jego istoty, stereotyp ma za zadanie uprościć odbiór otaczającej rzeczywistości i procesów w niej zachodzących ${ }^{3}$. W.Lippman, wprowadzając pojęcie stereotypu do nauk społecznych i humanistycznych, pisał o stereotypach jako: pictures in our heads, powszechnie utartym, szeroko podzielanym i nadmiernie generalizującym przedstawieniom rzeczywistości. Termin obraz został następnie zastąpiony terminem reprezentacja umysłowa ${ }^{4}$.

Interesującej odpowiedzi na pytanie, czym jest stereotyp, udziela J. Błuszkowski. Według badacza stereotyp jest formą świadomości społecznej, na którą składa się pięć podstawowych komponentów: kognitywny (uproszczenie rzeczywistości), empiryczny (niezależność od doświadczenia), walencyjny (obecność ocen emocjonalnych i sądów wartościujących), lingwistyczny (powiązanie ze słowem aktywizującym) i inwariancyjny (trwałość i niezmienność) ${ }^{5}$. Definicja J. Błuszkowskiego zakłada skalarność poszczególnych komponentów, np. dla komponentu kognitywnego stopień zgodności z faktami: prawdziwe, częściowo prawdziwe, fałszywe czy w przypadku komponentu walencyjnego stopień i kierunek zabarwienia emocjonalnego: od pozytywnych, przez neutralne po negatywne, itp. Skalarność komponentów stereotypu wpływa na jego wyrazistość. Im bliżej krańca skali, tym stereotyp jest bardziej wyrazisty i tendencyjny 6 . Takie formy, według Z. Chlewińskiego, cechują się subiektywną pewnością odnośnie trafności spostrzeganych zjawisk społecznych,

2 Por.:Z. Chlewiński, Stereotypy: struktura, funkcje, geneza. Analiza interdyscyplinarna, «Kolokwia Psychologiczne» 1992, t. 1, s. 10 i n.; Z. Bokszański, Stereotypy a kultura, Wrocław 1997, s. 22-24.

${ }^{3}$ Por.I. Kurcz, Zmiana stereotypów:jej mechanizmy igranice, [w:] M. Kofta, A. Jasińska-Kania (red.), Stereotypy i uprzedzenia. Uwarunkowania psychologiczne i kulturowe, Warszawa 2001, s. 3-6;

4 Tamże, por. W. Lippmann, Public Opinion, New York-London 1965, s. 3-20, 53-100.

5 J. Błuszkowski, Stereotypy narodowe w świadomości Polaków. Studium socjologiczno-politologiczne, Warszawa 2003, s. 9 i n., 49.

${ }^{6}$ Tamże, s. 53. 
co przejawie się braku miejsca na sądy probabilistyczne ${ }^{7}$. Systematyzując występowanie stereotypów w społeczeństwie J. Błuszkowski proponuje schemat podmiotowo-przedmiotowej kategoryzacji stereotypów, który dotyczy ogółu społeczeństwa, wybranych segmentów społecznych oraz jednostek ludzkich.

Diagram 1. Schemat podmiotowo-przedmiotowej klasyfikacji stereotypów

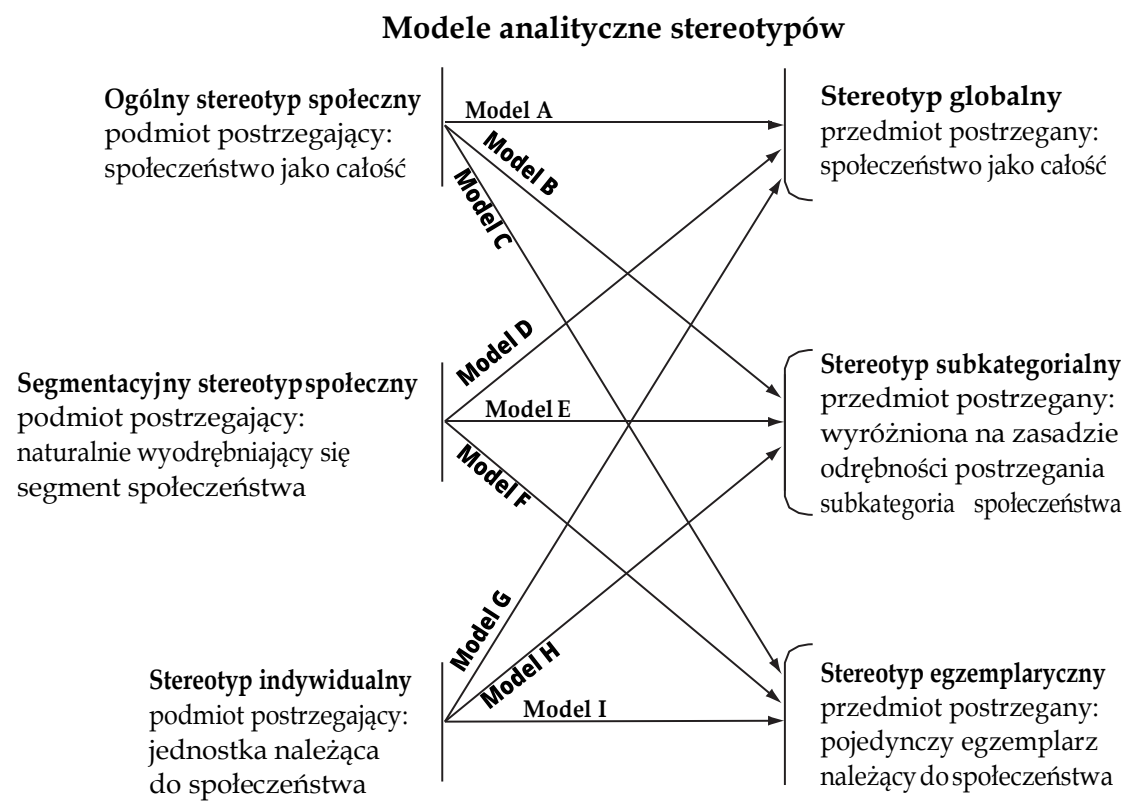

Źródło: J. Błuszkowski, Metodologiczne problemy badań nad stereotypami elit politycznych w krajach WNP, [w:] T.Bodio (red.), Przywództwo, elity i transformacje w krajach WNP, vol. 1, Warszawa 2010, s. 309.

Rozważając kwestie stereotypów polityków w kampaniach wyborczych, a szerzej w polityce, warto rozwinąć przywołaną klasyfikację. Przyjmując założenie, że jedną z subkategorii społecznych będących przedmiotem stereotypu są politycy, można wyróżnić ich trzy poziomy percepcji:

- politycy jako całość: grupa społeczna uczestnicząca w sprawowaniu władzy;

- politycy jako element całości: wyodrębnione grupy ze względu na organizację w partiach politycznych ${ }^{8}$

- jednostkowi aktorzy polityczni.

${ }^{7}$ Z. Chlewiński, Stereotypy: struktura, funkcje..., s. 12.

${ }^{8} \mathrm{~W}$ tym przypadku można też mówić o koalicjach politycznych lub ruchach społecznych, mających charakter polityczny. 
Należy jednak pamiętać, iż stereotypizacja nie ogranicza się tylko jednostek ludzkich i społeczności. J. Błuszkowski, odwołując się do dorobku jednego z pionierów badań nad stereotypami S.A. Rice, zaznacza, że w szerszym ujęciu przedmiotem stereotypu są np. instytucje i doktryny ${ }^{9}$. Zbiór ten nie jest zamknięty, warto włączyć do niego stereotypowe reprezentacje procesów: transformacji, prywatyzacji, integracji europejskiej itp.

Rozwijając natomiast aspekt podmiotowy klasyfikacji J. Błuszkowskiego trzeba zauważyć, że analizy stereotypów politycznych, które w literaturze przedmiotu prowadzone są głównie z punktu widzenia poziomu ogólnospołecznego, bywają niewystarczające, by zrozumieć specyfikę stereotypów politycznych. Takie postępowanie często skutkuje włączeniem w profil odtwarzanego stereotypu cech przeciwstawnych, co bezpośrednio wynika $\mathrm{z}$ heterogeniczności społeczeństwa, różnic $\mathrm{w}$ preferencjach politycznych i światopoglądowych. Zasadnym jest zatem wyodrębnienie segmentów społecznych ze względu na udzielane/deklarowane poparcie dla danej partii politycznej czy wyznawany światopogląd, co winno uwidocznić przede wszystkim różnice w treści i znaku walencyjnym stereotypów danych subkategorii i egzemplarzy politycznych, wskazując na oś stereotypowego podziału my - oni czy swoi - obcy.

Podmiotowy wymiar klasyfikacji J. Błuszkowskiego wyodrębnia też poziom indywidualny, który stoi w opozycji do kulturowo-społecznego podejścia w wyjaśnianiu stereotypów jako zjawisk grupowych. Poziom indywidualny powiązany jest z podejściem psychodynamicznym, gdzie eksplanacja skupia się głównie na cechach osobowości, predysponujących do sięgania i tworzenia sztywnych, tendencyjnych stereotypowych reprezentacji ${ }^{10}$. Jest to istotne $\mathrm{z}$ punktu widzenia analizy wpływu cech osobowości na treść, zabarwienie emocjonalne oraz podłoże-społecznokulturowe stereotypów wprowadzanych do debaty publicznej przez liderów politycznych ${ }^{11}$.

W związku z powyższym, analizując stereotypy w odniesieniu do kampanii wyborczych, wartą nadmienienia jest sytuacja, kiedy to politycy są zarówno podmiotem, jak i przedmiotem stereotypu, powielając lub kreując je w debacie publicznej. W szerokim ujęciu na temat doktryn, instytucji, procesów, a w wąskim na temat własnych ugrupowań - autostereotypy i innych ugrupowań - heterostereotypy ${ }^{12}$. Przekaz ten

${ }^{9}$ Zob. tamże, s. 55.

${ }^{10}$ I. Kurcz, Zmienność i nieuchronność stereotypów, Warszawa 1997, s. 21 i n.

11 Por. E.M. Marciniak, Personalizacja zachowań wyborczych w Polscew kontekście Modelu Zgodności Preferencji Politycznych, Warszawa 2013, s. 177-200.

12 Por. I. Kurcz, Zmienność i nieuchronność..., s. 34. 
skierowany jest do zewnątrz: elektorat, otoczenie instytucjonalne i międzynarodowe oraz do wewnątrz: członkowie partii.

\section{Rola stereotypów w kampaniach wyborczych}

Współcześnie wyborca zanim podejmie decyzję, na kogo oddać swój głos, uczestnicząc w zmediatyzowanym ${ }^{13}$ świecie, gdzie dominuje kultura masowa, a komunikacja polityczna podporządkowana jest zasadom kampanii permanentnej ${ }^{14}$, narażony jest na odbiór sprzecznych ze sobą komunikatów, emitowanych przez aktorów życia politycznego, reprezentujących poszczególne strony konfliktu. Informacje przekazywane za pomocą mediów mogą przybierać postać stereotypów z powodu „,niedoskonałości przekazu (szumy), bądź ze świadomych zamierzeń nadawców informacji”" 15 . Według jednego z pierwszych badaczy stereotypów i uprzedzeń, którym był G.W. Allport, mass-media odgrywają niepoślednią rolę w utrwalaniu lub zmianie stereotypowych reprezentacji ${ }^{16}$. Z punktu widzenia teorii stereotypu wielość i różnorakość informacji, jakie docierają do wyborcy masowego, posiadającego pewne preferencje polityczne, $\mathrm{z}$ jednej strony zmuszają go do radzenia sobie $\mathrm{z}$ nadmiarem informacji, skracania drogi poznawczej i sięgania do utartych, zgeneralizowanych, podzielanych społecznie i panujących w środowisku w jakim funkcjonuje, czy grupie społecznej w której uczestniczy lub z którą się utożsamia, stereotypowych reprezentacji umysłowych ${ }^{17}$ na temat innych grup społecznych, ruchów, partii politycznych, ich liderów, procesów, wydarzeń czy np. otoczenia międzynarodowego itp.

$\mathrm{Z}$ drugiej zaś strony taka sytuacja obliguje emitentów komunikatów politycznych do formowania prostych, skondensowanych w treści i ładunku afektywno-ewaluacyjnym komunikatów, które są zgodne i aktywują system stereotypów wytworzony, a częstokroć nie tyle co wytworzony, a wykreowany w świadomości grup docelowych poprzez działa-

${ }^{13}$ Zob. O. Annusewicz, D. Piontek, Polityka popularna: celebrytyzacja polityki, politainment, tabloidyzacja, «e-Politikon» 2013, nr 5, s. 8 i n., http://oapuw.pl/wp-content/uploads/2013/06/epolitikon-5-2013.pdf (11.01.2020).

${ }^{14}$ Zob. J. Garlicki, Komunikowanie polityczne - od kampanii wyborczych do kampanii permanentnej, «Studia Politologiczne» 2010, vol. 16, s. 33-35.

${ }^{15}$ D. Piontek, Stereotyp: geneza, cechy, funkcje, [w:] K. Borowczyk, P. Pawełczyk (red.), Wkręgumitówistereotypów, Torun 1993, s. 30.

16 ZaI. Kurcz, Zmiennośći nieuchronność..., s. 12.

${ }^{17}$ Por. I. Kurcz, Zmiana stereotypów..., s. 7. 
nia marketingowo-propagandowe ${ }^{18}$, oparte na wzorcach zaczerpniętych z tradycji kulturowej w odniesieniu do interpretacji wydarzeń bieżących. Z. Mitosek twierdzi, że stereotyp jawi się jako warunek komunikacji propagandowej, a także jako obiekt operacji perswazyjnej ${ }^{19}$. Według D. Piontek użycie stereotypów ma zwiększyć skuteczność przekazu i doprowadzić odbiorców do przyjęcia pożądanych z punktu widzenia nadawcy postaw $^{20}$.

Teoretyk, jak i praktyk działań propagandowych i ideologicznych A. Schaff - wskazuje, iż stereotypy wielorako są powiązane z działaniem społecznym człowieka, co ma swoje odzwierciedlenie w języku polityki i w ideologii ${ }^{21}$. Poprzez swoją sztywność, stabilność i niezależność od doświadczenia powodują stan umysłu zamkniętego na argumenty przeciwnika. Stereotypy bronią danej ideologii, a myślenie ideologiczne wpływa na powstawanie i utrwalanie stereotypów w myśleniu wyborców. Według niego stereotypy są wręcz niezbędnym instrumentem $\mathrm{w}$ arsenale walki politycznej22. Dzięki stereotypom można trafić do mas ludzkich, a nie tylko wybranych, elitarnych kręgów i zagwarantować sobie stabilność pożądanych postaw ${ }^{23}$.

Powyższe ustalenia są istotne $\mathrm{w}$ związku $\mathrm{z}$ komunikowaniem politycznym i kampanią wyborczą, która jest szczególnym momentem w życiu politycznym. W tym okresie każda partia oraz każdy kandydat, którzy pretendują do sprawowania władzy w zintensyfikowany sposób muszą zaprezentować siebie samych w opinii publicznej. Rozpatrując zagadnienie kampanii wyborczej pod kątem stereotypu, warto odwołać się do istotnych z przedmiotowego punktu widzenia ustaleń poczynionych przez E. Pietrzyk-Zieniewicz, A. Sokołowskiego i A. Zieniewicza. Badacze, co bezpośrednio koreluje z lippanowskim ujęciem stereotypu jako obrazu, uważają, że autoprezentacja jest portretem zbiorowego autorstwa. Autorem jest sztab, który wybranymi środkami propagandowymi ma realizować pożądany obraz kandydata czy partii. Charakter zbiorowy nawiązuje do sytuacji, gdzie odpowiedni obraz tworzony jest na tle przewidywanej zgody elektoratu i będzie podlegać jego realistycznym cenzurom. Nie

\footnotetext{
${ }^{18}$ Nie należy mylić pojęcia propagandy jako komunikowania perswazyjnego z jej stereotypową reprezentacją: propagandy jako kłamstwa. Por. B. Dobek-Ostrowska, J. Fras, B. Ociepka, Teoria i praktyka propagandy, Wrocław 1997, s. 10.

${ }^{19}$ Z. Mitosek, Stereotyp a literatura, Wrocław 1974, s. 97.

${ }^{20}$ D. Piontek, Stereotyp: geneza, cechy..., s. 30.

${ }^{21}$ A. Schaff, Stereotypy a działanie ludzkie, Warszawa 1981, s. 142.

22 Tamże, s. 132.

23 Tamże, s. 135.
} 
może zatem zbytnio odbiegać od życzeń i oczekiwań, które wytworzyły się w świadomości społecznej. Według nich słowo portret należy przyrównać do aktualizacji wiedzy naszego elektoratu o nas samych. Ma on za zadanie przenieść zasady programu i ideologię na psychospołeczne wyobrażenia, dotyczące partii czy danego kandydata w działaniu i być opisywalnym w kategoriach społecznej mitologii. Wyróżniają cztery pragmatyczne funkcje kampanii wyborczej, które mogą być realizowane podczas autoprezentacji: lokalizacyjną, wartościująco-postulatywną, socjotechniczną i programową ${ }^{24}$. Funkcje te korelują z czterema podstawowymi funkcjami stereotypu: poznawczą, integracyjną, obronną i adaptacyjną ${ }^{25}$.

\section{Funkcja lokalizacyjna - orientacja na scenie politycznej}

Funkcja lokalizacyjna dotyczy przedstawienia legitymizacji do sprawowania władzy, poprzez określenie się na scenie politycznej. Lokalizacja ma odpowiedzieć na pytanie, skąd przychodzimy, a dokładniej,,z jakich historycznych, społecznych, politycznych, religijnych okoliczności wykrystalizowaliśmy się jako grupa pretendująca do parlamentarnych foteli" 26 . Wykorzystywane są tu stereotypy już funkcjonujące w kulturze politycznej danego społeczeństwa, a także jest miejsce na tworzenie nowych, determinowanych specyfiką sceny politycznej i wydarzeniami bieżącymi. W tradycyjnym ujęciu polityki lokalizacja następuje na bazie wyznawanych poglądów, ideologii i doktryn, które oprócz tego, że jako pojęcia, funkcjonują także jako stereotypy ${ }^{27}$. W tym miejscu można wyróżnić lokalizację lewicową, centrową, prawicowąlub np.: liberalną, socjalną, konserwatywną.

Jednakowoż $w$ polskich realiach, determinowanych transformacją ustrojową, należy zwrócić uwagę na jeszcze inny stereotypowy podział, którego początkowo główną osią my - oni był podział związany z obradami okrągłego stołu. Dzielił on ugrupowania na mające rodowód solidarnościowy i komunistyczny. Nawiązuje on do tradycyjnego stereotypu funkcjonującego w polskiej kulturze politycznej, stereotypu walki, który

${ }^{24}$ E. Pietrzyk-Zieniewicz, A. Sokołowski, A. Zieniewicz, Jak Polak z Polakiem: kampania wyborcza do Sejmu i Senatu RP w 1993 r.: autoprezentacje, regionalne uwarunkowania postaw wyborczych, dyskursy, analizy, Ciechanów 1998, s. 11.

25 Por. M. Ludwiniak, Teoretyczne aspekty stereotypów politycznych, [w:] W. Jakubowski,

A. Krawczyk, J. Szczepański(red.), Nowespojrzeniaw naukachopolityce, t. 2, Warszawa 2012, s. 145-147.

${ }^{26}$ E. Pietrzyk-Zieniewicz, A. Sokołowski, A. Zieniewicz, Jak Polak..., s. 11.

27 A. Schaff, Stereotypy a działanie..., s. 110-115. 
począwszy od zaborów replikowany był również w okresie wojennym, podczas dominacji sowieckiej, a następnie transformacji systemowej. Stereotyp ten dzieli scenę polityczną na osoby walczące o wolność i niezależność państwa w przeciwieństwie do polityków realizujących obcy interes i oparty jest na motywie zdrady.

Ponadto lokalizacja odbywa się również na bazie negatywnego stereotypu polityków jako warstwy społecznej i kontestacji bieżących elit politycznych, dając możliwość do umiejscowienia się jako partii antysystemowej lub spoza systemu. Lokalizacja spoza systemu może przybierać również charakter pozytywny jako ruchu/partii politycznej, niosącej progresywne, reformatorskie hasła, niekoniecznie negujące zastany ład, a raczej go modernizujące. Lokalizacja może też dotyczyć określonej warstwy społecznej - np. ludowa, inteligencka czy korzeni w ruchach społecznych, czego dobrym przykładem są partie nawiązujące do ruchów LGBT. W odniesieniu do wartości religijnych, trzeba zwrócić uwagę na lokalizację chrześcijańską i antyklerykalną.

Lokalizacja na scenie politycznej nie musi odnosić się tylko do jednego stereotypu, a często występuje jako system kilku połączonych ze sobą i uzupełniających się stereotypów. Proces ten można zawęzić do etykiet, jakie przyporządkowane są danym partiom politycznym i ich reprezentantom, komponent lingwistyczny stereotypu, bodziec słowny, powoduje ewokację treści i zawartych w stereotypie emocji oraz ewaluacji. Stereotyp realizuje tu swoją funkcję poznawczą, ma za zadanie uprościć i uporządkować rzeczywistość polityczną, stworzyć całościowy system orientacyjny, który cechuje się przejrzystością i względną stabilnością28. Jakkolwiek wykorzystanie stereotypów w funkcji lokalizacyjnej kampanii wyborczej nie pozwalałoby na szybką i łatwą lokalizację danego podmiotu na mapie systemu orientacyjnego wyborcy, tak należy zadbać o to, by wykorzystane w identyfikacji stereotypy miały odpowiednie zabarwienie emocjonalne i pożądaną treść, czego zadaniem są pozostałe trzy pragmatyczne funkcje kampanii wyborczej.

\section{Funkcja wartościująco-postulatywna - autostereotypy i metastereotypy}

Funkcje wartościująco-postulatywna i socjotechniczna dotyczą wykorzystania odpowiednich autostereotypów i heterostereotypów. W pierw-

${ }_{28}$ J. Błuszkowski, Stereotypy narodowe..., s. 45. 
szej z nich należy stworzyć autoportret własny i powiązać go z konstrukcją wizji elektoratu. Należy ,ująć ten elektorat jako pewne MY, opatrzone zacnymi cechami uczuciowości i charakteru, cechami, które najświetniej się przejawiły w postaci naszego lidera" 29 . Autostereotyp jest charakterystyczną odmianą stereotypu, gdzie podmiot postrzega siebie samego, jest obrazem własnym grupy, w którym tożsamość jest odtwarzana i chroniona. Zajmuje zatem centralne miejsce w systemie stereotypów, a silne przywiązanie do obrazu własnego jest źródłem jego trwałości i sztywności ${ }^{30}$. Stosowane $\mathrm{w}$ funkcji wartościująco-postulatywnej stereotypy dotyczą zarówno komunikacji do elektoratu, jak również do członków własnego ugrupowania, co powoduje odtwarzanie i utrwalanie tożsamości grupowej.

Dwoma głównymi autostereotypami, funkcjonującymi w polskim społeczeństwie, wokół których często budowana jest komunikacja w kampanii wyborczej, są stereotyp tradycyjny i antycypacyjny. Pojęcie autostereotypu tradycyjnego nawiązuje do faktu, iż został on ukształtowany w przeszłości. Pamięć historyczna każdego narodu jest zatem składnikiem niezbywalnym dla autostereotypu. Autostereotyp tradycyjny przyjmuje postać patriotyczno-heroiczną, składają się na niego trzy następujące sylwetki: katolika, patrioty i człowieka honoru. Stereotyp antycypacyjny natomiast krystalizuje się w kulturze politycznej polskiego społeczeństwa na bazie zachodzących zmian i transformacji systemu politycznego, oparty jest na modernizacji, otwartości i integracji europejskiej ${ }^{31}$.

Oprócz cech zawartych w autostereotypach ogólnospołecznych, należy zadbać także o ekspozycję pozytywnych, szczególnie wyrazistych cech indywidualnych ${ }^{32}$, charakteryzujących liderów politycznych, które zgodnie z teorią kategoryzacji wpływają na spostrzeganie grupy jako całości, w tym wypadku partii politycznej. O ile teoria kategoryzacji zakłada, że to jednostka kategoryzowana jest na podstawie uproszczonej reprezentacji umysłowej grupy, do której przynależy ${ }^{33}$, tak w przypadku kategoryzacji wyrazistych liderów politycznych, w związku z ich specyficzną rolą społeczną należy odwołać się do zjawiska personalizacji ${ }^{34}$ i założyć, że

\footnotetext{
${ }^{29}$ E. Pietrzyk-Zieniewicz, A. Sokołowski, A. Zieniewicz, Jak Polak..., s. 11, 21.

30 J. Błuszkowski, Stereotypy a tożsamość narodowa, Warszawa, 2005, s. 117.

31 J. Błuszkowski, Stereotypy narodowe..., s. 16, 238-247.

${ }^{32}$ I. Kurcz, Zmiana stereotypów..., s. 8.

33 Tamże, por. T.D. Nelson, Psychologia Uprzedzeń, Gdańsk 2003, s. 43-45.

34 Zob. E.M. Marciniak, Personalizacjazachowań wyborczych..., s. 11 in., 25-30; D.Piontek, Personalizacja jako efekt mediatyzacji polityki, «SSrodkowoeuropejskie Studia Polityczne» 2015, nr 3, s. 94-101.
} 
kategoryzacja może przebiegać w odwrotnym kierunku: przywódca polityczny determinuje reprezentację umysłową grupy. W pośrednim przypadku kategoryzacja występuje dwukierunkowo i jest ze sobą sprzężona. B. Biskup koncentrację na kandydacie własnym lub na rywalu, włącza do klasyfikacji form strategii wyborczych ${ }^{35}$. Nawiązując do badań przeprowadzonych w 2012 r., w skład profilu stereotypu abstrakcyjnego - idealnego przywódcy politycznego - wchodzą następujące cechy: uczciwy, inteligentny, odpowiedzialny, wiarygodny, wykształcony, kompetentny, skuteczny, dbający o dobro wspólne, pracowity.

Konstrukcja wspólnotowego MY równolegle do autostereotypów, może się również odbywać poprzez użycie metastereotypów. Pojęcie metastereotypu zostało wprowadzone do nauki w roku 1998 przez J.D. Vorauer, K.J. Main, G.B. O’Connell i opisuje sytuację, w której określony podmiot projektuje obraz grupy własnej w świadomości grupy obcej ${ }^{36}$. Metastereotyp jest zatem odpowiedzią na pytanie: jak ONI widzą NAS? Instrumentalne wykreowanie i zastosowanie metastereotypu w walce o władze może dotyczyć sytuacji, w której pozytywnie przedstawiany jest obraz grupy własnej w świadomości innych grup uważanych za wpływowe. Ten casus odnosi się np. do eksponowania pozytywnego metastereotypu grupy własnej, przykładowo partii rządzącej, w świadomości otoczenia międzynarodowego. Następuje wtedy projekcja siły, skuteczności, uznania, podziwu itp. Z drugiej strony można wyróżnić sytuację, kiedy to grupa własna, dla przykładu partia opozycyjna, używa negatywnego metastereotypu wspólnotowego MY, którego nosicielem jest władza, dyskryminująca, marginalizująca wspólnotowe MY, pretendujące do zdobycia władzy, by tę niekorzystną sytuację zmienić. Pojęcie metastereotypu nie było do tej pory rozpatrywane na gruncie literatury polskiej ${ }^{37}$, stąd podane przykłady jedynie sygnalizują tę problematykę i mają charakter poglądowy, a samo zagadnienie wymaga dalszego rozwinięcia. Wykorzystanie stereotypów w konstrukcji wartościująco-postulatywnego MY jest zasadne ze względu na ich funkcję integracyjną. Pozwala zdefiniować i odtwarzać i aktualizować własną tożsamość oraz zbudować wspólnotę przekonań i wartości, a także porównać się na tle innych.

35 B. Biskup, Strategie w kampanii wyborczej - rodzaje, znaczenie, zastosowanie, «Studia Politologiczne» 2010, vol. 16, s. 48 i n.

$36 \mathrm{Za}$ : K. Jiyoon, O. Tomoko, Meta-stereotype as an indicator of intergroup attitude: How Japanese perceive theyareviewed by Koreans, «JapanesePsychological Research»2009, vol.51, s. 279, https://onlinelibrary.wiley.com/doi/epdf/10.1111/j.1468-5884.2009.00411.x (15.01.2020.)

$37 \mathrm{~W}$ przywoływanej pracy I. Kurcz występują wzmianki nt. wyobrażeń własnego stereotypu u innych. Zob. I. Kurcz, Zmiana stereotypów..., s. 13. 


\section{Funkcja socjotechniczna - heterostereotypy}

Wykorzystanie negatywnego heterostereotypu innych, obcych - ONI - odnosi się do funkcji socjotechnicznej, gdzie w skrajnym przypadku tworzony jest obraz wroga - tego, z którym prowadzona jest walka, kto zdradził, nie spełnił oczekiwań, kto jest zagrożeniem. Stereotyp wroga powoduje, że w świadomości uruchamiane są pozostałe funkcje: „określa mianowicie naszą lokalizację przeciw obcemu, krystalizuje wspólnotowe MY wobec wroga, a tym samym precyzuje wartości i postulaty, przetwarzając jej jednocześnie w konkretny program walki ze złem"38. Przedmiotem heterostereotypu może być polityk/politycy konkurencyjnych partii politycznych, politycy reprezentujący rządy innych państw lub organizacji międzynarodowych, instytucji, grupy interesu lub grupy odmienne światopoglądowo, etnicznie, klasowo, kulturowo czy religijnie, które w kampanii wyborczej/permanentnej poddawane są procesowi demonizacji.

Stereotyp ten w swoim wymiarze walencyjnym opiera się na emocjach lęku i strachu. W krańcowej formie trwałe odbicie obrazu wroga w głowach ludzi przyjmuje postać stereotypu spiskowego ${ }^{39}$, zwanego również stereotypem duszy grupowej ${ }^{40}$. Podłożem myślenia spiskowego jest manichejska, dychotomiczna wizja rzeczywistości, która składa się z kategorii ludzi czystych i nieczystych. Jest to rozdział na dobro i zło czy boskość i diabelskość. Elementami charakterystycznymi dla stereotypu spiskowego są: przypisywanie grupie obcej dyspozycji do czynienia zła, spójność poczynań grupy obcej, która działa tak, jakby była jednostką, założenie, iż wroga aktywność sterowana jest $\mathrm{z}$ jakiegoś mistycznego miejsca oraz przekonanie, że grupa działa w sposób niewidzialny, a dostrzec można tylko efekty tego działania ${ }^{41}$. Stereotyp w funkcji socjotechnicznej ma znaczenie ze względu na jego funkcje obronne. Utożsamia faworytów politycznych jako tych, którzy chronią przed wspólnym wrogiem wartości i interesy grupowe oraz osobiste, zintegrowane wokół wspólnotowego MY.

\footnotetext{
${ }^{38}$ E. Pietrzyk-Zieniewicz, A. Sokołowski, A. Zieniewicz, Jak Polak.., s. 11 i n., 29.

${ }^{39}$ M. Kofta, Stereotyp spiskowy jako centralny składnik antysemityzmu, [w:] M. Kofta i A. Jasińska-Kania (red.), Stereotypy i uprzedzenia. Uwarunkowania psychologiczne $i$ kulturowe, Warszawa 2001, s. 274.

${ }^{40}$ M. Grzesiak-Feldman, Tożsamościowe uwarunkowania posługiwania się stereotypami, Warszawa 2006, s. 15.

41 Tamże, s. 18; M. Kofta, Stereotyp spiskowy jako..., s. 277.
} 


\section{Funkcja programowa - projekcja ładu społecznego}

Funkcja programowa odpowiada za stworzenie obrazu siebie samego u władzy ${ }^{42}$. Abstrahując od poszczególnych postulatów programu wyborczego, użycie stereotypu powinno w głównej mierze tworzyć spójny obraz państwa jako instytucji, organizującej życie społeczne. Pozytywny stereotyp państwa powiązany jest z rządami partii własnej zarówno, jeśli dana partia sprawuje obecnie władzę, jak i w momencie, kiedy się o nią ubiega, antycypując przyszły ład społeczny. Pozytywny stereotyp państwa eksponowany w kampanii wyborczej może być konfrontowany z jego negatywnym przeciwieństwem, czyli wizją państwa rządzonego przez konkurencję polityczną.

W stereotypie pozytywnym, oprócz manifestacji cech, charakterystycznych dla tworzonego państwa, będą się zawierać stereotypy użyte w innych funkcjach kampanii wyborczej: państwo dbające o ideały i wartości, poprzez które dokonywana jest lokalizacja na scenie politycznej, działające na rzecz upodmiotowienia i reprezentacji interesów grup zawartych w konstrukcji wspólnotowego MY, a także ograniczające wpływy grup obcych, działających na jego szkodę. Program wyborczy, w swym klasycznym rozumieniu, ma natomiast za zadanie wskazać instrumenty, służące do realizacji stereotypu państwa, tworzonego na potrzeby kampanii wyborczej, czego ekwiwalentem są obietnice wyborcze. Zastosowanie stereotypu w funkcji programowej kampanii realizuje jego funkcje adaptacyjne, przedstawia pewien ład społeczny, dając poczucie stabilności, pewności i bezpieczeństwa lub ich braku w zależności zwycięstwa danej partii politycznej.

Odwołując się do stereotypów państwa w realiach polskiej polityki, akcent należy położyć na ocenie dorobku transformacji ustrojowej. Pozytywny stereotyp III RP, bazujący na uznaniu i stopniowemu modernizowaniu ładu społecznego przeciwstawiany był próbie stworzenia nowego państwa, które w pewnym momencie przyjęło nawet lingwistyczną formę IV RP. W ostatnich pięciu latach spór toczył się o budowę państwa dobrobytu dla wcześniej marginalizowanych ,zwykłych obywateli”, przeciwstawianej państwu budowanemu na braku poszanowania praworządności i stawiającemu pod znakiem zapytania pewien ład międzynarodowy i obecność Polski w Unii Europejskiej.

${ }^{42}$ E. Pietrzyk-Zieniewicz, A. Sokołowski, A. Zieniewicz, Jak Polak..., s. 11 i n. 


\section{Podsumowanie: główna oś podziału MY - ONI w ostatnich 15. latach w Polsce}

Biorąc pod uwagę realia walki politycznej w Polsce, należy stwierdzić, że spór pomiędzy Platformą Obywatelską, a Prawem i Sprawiedliwością, a następnie między Koalicją Europejską/Obywatelską, a Zjednoczoną Prawicą w dużej części zagospodarował debatę publiczną, komunikacja polityczna stała się wyjątkowo agresywna i nacechowana skrajnie negatywnymi emocjami, pełna wzajemnych oskarżeń i szkalowań. Takie środowisko sprzyja powstawaniu, kreowaniu i utrwalaniu tendencyjnych stereotypów w myśleniu wyborców. Tragiczne wydarzenia z 2010 roku spotęgowały działania stron konfliktu na rzecz tworzenia i utrwalania negatywnych i skrajnych heterostereotypów. Polaryzacja w środowisku elit politycznych odciskała piętno na języku i stosowanej propagandzie i rzutowała na społeczeństwo. Dokonała się materializacja negatywnych heterostereotypów, które przybrały formę stygmatów społecznych w postaci: „zdrajców”, czy „oszołomów” w przeciwieństwie do autostereotypów „prawdziwych Polaków” czy „ludzi postępowych”. „Polska w budowie” przeciwstawiana była „Polsce w ruinie”, a „,przemysł pogardy” „mowie nienawiści"43.

Są to tylko niektóre z przykładów skrajnych, stereotypowych konstrukcji, będących komponentami systemu stereotypów politycznych w Polsce. Elementami centralnymi tego systemu byli przywódcy polityczni, w tym przypadku J. Kaczyński i D. Tusk. Konflikt w elitach rzutował na społeczeństwo i jego głęboką polaryzację. Obecnie obydwaj politycy bardziej lub mniej pozornie odsunięci są od oficjalnej polityki państwowej, a ich role przejęli inni aktorzy polityczni, lecz wygenerowany konflikt wartości wśród elit politycznych był jednym z głównych powodów tranzycji przywództwa politycznego w Polsce i pojawieniu się nowych aktorów politycznych na stanowiskach przywódczych.

We wstępie pracy wskazana jest luka w badaniach nad stereotypami w subdyscyplinach polskiej politologii: psychologii polityki i socjologii polityki, gdzie według autora pojęcie stereotypu jest pomijane lub marginalizowane. Wyeksponowane zostaje rozproszenie i brak kontynuacji badań, w których stereotyp traktowany byłby jako kategoria centralna, wyjaśniająca pewne zjawiska polityczne. Następnie przywołane zostają

43 Por. K. Kłosińska, Rola procesów nominacyjnych w tworzeniu opozycji „my”/,oni” w języku polityki po 1989 roku, [w:] P. Krzyżanowski, P. Nowak (red.), Manipulacja w języku, Lublin 2004, s. 115-122. 
podstawowe definicje stereotypu, występujące w literaturze przedmiotu $\mathrm{Z}$ akcentem na definicję sprawozdawczą, sporządzoną przez J. Błuszkowskiego w odniesieniu do subiektywnej pewności jako istotnej cechy natury stereotypu oraz relacji podmiotowo-przedmiotowej, gdzie istotną z punktu widzenia kampanii wyborczej jest sytuacja, w której przedmiotem i podmiotem stereotypu są właśnie politycy. Ponadto występuje odwołanie do heterogeniczności społeczeństwa i odmienności na poziomie segmentu ze względu na światopogląd i preferencje polityczne oraz ze względu naindywidualne predyspozycje charakterologiczne jednostki. Aspekt przedmiotowy rozwinięty jest w odniesieniu do trzech poziomów stereotypizacji polityków: grupa społeczna uczestnicząca w sprawowaniu władzy, odrębne grupy zorganizowane w partiach politycznych i jednostkowi aktorzy polityczni.

Rozwinięcie prymarnych założeń, dotyczących stereotypów, następuje poprzez aplikację tegoż pojęcia wobec pragmatycznych walorów polityki jako walki wyborczej, gdzie wskazana jest rola tychże w percepcji polityki, postawach, ideologiiidziałaniachmarketingowo-propagandowych. Pozwala to na odniesienie problematyki stereotypów do kampanii wyborczych i wyróżnienia czterech podstawowych, pragmatycznych funkcji komunikacji politycznej w przededniu wyborów, czyli w kampanii wyborczej: lokalizacyjnej, wartościująco-postulatywnej, socjotechnicznej i programowej. Funkcje te rozpatrywane są w korelacji z czterema podstawowymi funkcjami stereotypu: poznawczą, integracyjną, obronną i programową.

Rozwinięcie związku funkcji stereotypów z pragmatycznymi funkcjami kampanii wyborczych realizowane jest w czterech kolejnych podrozdziałach. Funkcja lokalizacyjna powiązana zostaje z funkcją poznawczą stereotypu, mającą za zadanie stworzyć całościowy system orientacyjny w świecie wyborcy i odnosi się do nadawania etykiet z uwzględnieniem takich podziałów, jak: prawicowy, centrowy, lewicowy, konserwatywny, socjalny, liberalny, a także specyficznego dla sceny politycznej w Polsce i ciągle aktualnego podziału na ludzi walczących o wolność wobec ludzi służalczych dla obcych interesów. Wspomniany jest też podział związany z religiąi dotyczący lokalizacji chrześcijańskiej orazantyklerykalnej. Opracowanie funkcji wartościująco-postulatywnej kampanii wyborczej skorelowane jest z funkcją integracyjną stereotypu, tj. kształtowaniem i aktualizowaniem tożsamości elektoratu i członków partii politycznych. Podstawowymi przykładami są tu autostereotyp tradycyjny i antycypacyjny społeczeństwa polskiego, wokół których tworzone są tożsamości dla partii politycznych i ich zwolenników. Na grunt polskiej nauki wprowadzone zostaje pojęcie metastereotypu, jako wyobrażenia nt. tego, jak inni postrzegają nas. Funk- 
cja socjotechniczna powiązana jest z wprowadzaniem negatywnych stereotypów grup zagrażających grupie własnej, stąd podkreślany jest związek z obronnymi funkcjami stereotypu. Stereotypowa konstrukcja wroga może dotyczyć polityków lub liderów konkurencyjnej partii politycznej, grup odmiennych kulturowo, etnicznie czy religijnie lub nawet instytucji i polityków reprezentujących rządy innych państw.

W funkcji programowej kładziony jest nacisk na projekcję ładu społecznego, co ma związek z funkcjami adaptacyjnymi społeczeństwa i odnosi się do stereotypu instytucji państwa. Wymienione tu zostają stereotypy III i IV RP oraz państwa dbającego o zwykłych obywateli wobec państwa nieszanującego praworządności. W konkluzjach autor przywołuje niektóre z stereotypowych konstrukcji, dotyczących: autostereotypów, heterostereotypów, metastereotypów i stereotypów państwa, charakterystycznych dla antagonizmu wytworzonego w głównej osi podziału polskiej sceny politycznej w ostatnich piętnastu latach, zogniskowanej wokół konfliktu PO-PIS i Koalicja Obywatelska-Zjednoczona Prawica, konkludując, iż konflikt w elitach wpłynął na polaryzację społeczeństwa i transyzcję przywództwa politycznego w Polsce.

\section{Bibliografia}

B. Biskup, Strategie w kampanii wyborczej - rodzaje, znaczenie, zastosowanie, «Studia Politologiczne» 2010, vol. 16.

J. Błuszkowski, Stereotypy a tożsamość narodowa, Warszawa 2005.

J. Błuszkowski, Stereotypy narodowe w świadomości Polaków. Studium socjologiczno-politologiczne, Warszawa 2003.

Z. Bokszański, Stereotypy a kultura, Wrocław 1997.

Z. Chlewiński, Stereotypy: struktura, funkcje, geneza. Analiza interdyscyplinarna, «Kolokwia Psychologiczne» 1992, t. 1.

D. Piontek, Stereotyp: geneza, cechy, funkcje, [w:] K. Borowczyk, P.Pawełczyk (red.), W kręgu mitów i stereotypów, Toruń 1993.

B. Dobek-Ostrowska, J. Fras, B. Ociepka, Teoria i praktyka propagandy, Wrocław 1997.

J. Garlicki, Komunikowanie polityczne - od kampanii wyborczych do kampanii permanentnej, «Studia Politologiczne» 2010, vol. 16.

M. Grzesiak-Feldman, Tożsamościowe uwarunkowania posługiwania się stereotypami, Warszawa 2006.

K. Jiyoon, O. Tomoko, Meta-stereotype as an indicator of intergroup attitude: How Japanese perceive they are viewed by Koreans, «Japanese Psychological Research» 2009, vol. 51.

K. Kłosińska, Rola procesów nominacyjnych w tworzeniu opozycji "my" ",oni" w języku polityki po 1989 roku, [w:] P. Krzyżanowski, P. Nowak (red.), Manipulacja wjęzyku, Lublin 2004.

M. Kofta, Stereotyp spiskowy jako centralny składnik antysemityzmu, [w:] M. Kofta i A. Jasińska-Kania (red.), Stereotypy i uprzedzenia. Uwarunkowania psychologiczne i kulturowe, Warszawa 2001. 
M. Kofta, Wprowadzenie do psychologii stereotypów i uprzedzeń, [w:] E. Gucwa-Leśny, M. Marody (red.), Podstawy życia społecznego w Polsce, Warszawa 1996.

I. Kurcz, Zmiana stereotypów: jej mechanizmy i granice, [w:] M. Kofta, A. Jasińska-Kania (red.), Stereotypy i uprzedzenia. Uwarunkowania psychologiczne i kulturowe, Warszawa 2001.

I. Kurcz, Zmienność i nieuchronność stereotypów, Warszawa 1997.

W. Lippmann, Public Opinion, New York-London 1965.

M. Ludwiniak, Teoretyczne aspekty stereotypów politycznych, [w:] W. Jakubowski, A. Krawczyk, J. Szczepański (red.), Nowe spojrzenia w naukach o polityce, t. 2, Warszawa 2012.

E.M. Marciniak, Personalizacja zachowań wyborczych w Polsce w kontekście Modelu Zgodności Preferencji Politycznych, Warszawa 2013.

E.M. Marciniak, Caprary i Zimbarda koncepcja dopasowania preferencji politycznych. Praktyczne implikacje, «Studia Politologiczne» 2011, vol. 22.

Z. Mitosek, Stereotyp a literatura, Wrocław 1974.

T.D. Nelson, Psychologia Uprzedzeń, Gdańsk 2003.

E. Pietrzyk-Zieniewicz, A. Sokołowski, A. Zieniewicz, Jak Polak z Polakiem: kampania wyborcza do Sejmu i Senatu RP w 1993r.: autoprezentacje, regionalne uwarunkowania postaw wyborczych, dyskursy, analizy, Ciechanów 1998.

D. Piontek, O. Annusewicz, Polityka popularna: celebrytyzacja polityki, politainment, tabloidyzacja, «e-Politikon» 2013, nr 5.

D. Piontek, Personalizacja jako efekt mediatyzacji polityki, «Środkowoeuropejskie Studia Polityczne» 2015, nr 3.

A. Schaff, Stereotypy a działanie ludzkie, Warszawa 1981. 